\title{
PENDIDIKAN BUDI PEKERTI DALAM AJARAN WEDA DAN IMPLEMENTASINYA PADA MASYARAKAT GRIYA DI KABUPATEN BULELENG
}

\author{
I Nengah Dwi Endra Suanthara \\ STKIP Agama Hindu Singaraja, Singaraja, Indonesia \\ Email: inengahdwiendra123@gmail.com
}

\begin{abstract}
ABSTRAK
Tujuan penelitian ini adalah: mengkaji nilai-nilai pendidikan budi pekerti dalam ajaran Veda dan implemntasi pendidikan budi pekerti dalam masyarakat Griya di Kabupaten Buleleng. Beberapa teori yang digunakan untuk mengkaji masalah yang diteliti antara lain; materi yang berhubungan griya, pendidikan Budi Pekerti dan Weda sebagai sumber pendidikan Budi Pekerti. Penelitian ini dirancang dengan penelitian emperik jenis deskriptif kualitatif Teknik Penentuan informan (Sampel) yang digunakan adalah purposive sampling dengan teknik snowball. Metode pengumpulan data yang digunakan dalam penelitian ini adalah wawancara, observasi dan dokumentasi/pencatatan dokumen. Sedangkan analisis data yang digunakan adalah: deskriptif kualitatif. Berdasarkan analisis data diperoleh hasil sebagai berikut. Pendidikan budi pekerti yang ditemukan dalam ajaran Weda antara lain: (a) menanamkan Sraddha (Keimanan) dan Religiusitas, (b) berbhakti kepada orang tua, (c) mencintai dan menghormati guru, (d) mencintai dan menghormati saudara, kakak dan adik, (e) mencintai dan menghormati sahabat dan teman-teman, (f) mencintai tanah air dan bangsa, (g) bersikap ramah dan berbicara manis, (h) mengembangkan kebajikan, (i) mengembangkan kesucian hati, (j) taat sembahyang dan rajin belajar, (k) kebenaran dan pengorbanan serta kegiatan yang benar, (I) kedamaian dan kesabaran, (m) kesetaraan gender, (n) hak azasi manusia, (o) demokrasi dan musyawarah mufakat, (p) keadilan, (q) tanggungjawab, keuletan, dan kerjasama, (r) penghargaan dan harmonis dengan lingkungan sosial dan alam. Semua nilai tersebut masih tetap terimplementasi dalam keluarga Griya dengan mengikuti perkembangan jaman termasuk IPTEK.
\end{abstract}

Kata Kunci: Pendidikan Budi Pekerti, Weda dan Masyarakat Griya.

\section{ABSTRACT}

The purpose of this study was to examine the values of character education in the Vedic and implementation of character education in the Griya community in Buleleng Regency. Some theories used to examine the problems studied include; material related to the book, Character and Vedic Education as a source of education for Pekerti. This study was designed with emperic research with qualitative descriptive techniques. Determination of informants (samples) used was purposive sampling with snowball techniques. Data collection methods used in this study were interviews, observation and documentation / recording of documents. While the data analysis used was: qualitative descriptive. Based on 
data analysis, the following results are obtained. The character education found in the Vedic teachings includes: (a) instilling Sraddha (Faith) and Religiosity, (b) serving the parents, (c) loving and respecting the teacher, (d) loving and respecting siblings, brothers and sisters, (e) love and respect friends and friends, (f) love the homeland and nation, ( $g$ ) be friendly and speak sweetly, (h) develop virtue, (i) develop heart purity, (j) obey prayer and be diligent learning, (k) truth and sacrifice and right activities, (I) peace and patience, $(\mathrm{m})$ gender equality, $(n)$ human rights, (o) democracy and consensus agreement, (p) justice, (q) responsibility, tenacity, and cooperation, ( $r$ ) appreciation and harmony with the social and natural environment. All of these values are still implemented in the Griya family by following the developments including science and technology.

Keywords: Character Education, Vedas and Griya Society.

\section{PENDAHULUAN}

Griya adalah tempat tinggal untuk para Sulinggih atau rohaniwan Hindu yang memiliki tradisi tentang "tatakrama kehidupan yang normatif baik dalam sikap dan perilaku secara turun-temurun". Tata kehidupan yang normatif meliputi: berpikir, berkata dan berbuat mengikuti dresta Griya: menggunakan bahasa singgih/halus, berpikir dan berperilaku yang baik. Mengingat Griya adalah tempat pendidikan yang pertama dan utama bagi anak, maka Griya memberii kontribusi yang signifikan terhadap pembentukan karakter dan budi pekerti anak. Oleh karena itu anak yang berasal dari Griya cenderung: sikap, tutur kata dan perilakunya baik. Karena mereka dididik dan terbiasa dengan lingkungan yang baik-baik. Kondisi seperti ini muncul secara alami dalam suatu proses pendidikan yang dipengaruhi oleh "budaya Griya". Budaya ini tersirat dalam tugas atau fungsi sulinggih sebagai tokoh spiritual. Dalam media online (http://stitidharma.org) dijelaskan bahwa, fungsi Sulinggih: 1) memimpin warga dalam upaya mencapai kebahagiaan rohani sesuai dengan perannya sebagai Guru Loka. 2) Ngelokapalasraya yaitu menjadi sandaran atau tempat bertanya tentang kerohanian, pelindung/penuntun dan pengayom masyarakat di bidang Agama Hindu, memberii petunjuk dan bimbingan di bidang tattwa, susila, dan upacara, muput upacara ritual atas permintaan warga. Fenomena yang nampak di lapangan bahwa kehidupan masyarakat Griya juga mengalami pergeseran nilai sejalan dengan perkembangan IImu Pengetahuan dan Teknologi (IPTEK). Langsung maupun tidak langsung IPTEK berpengaruh terhadap interaksi dan tatakrama komunikasi di dalam Griya itu sendiri. Sistem komunikasi antara sulinggih dengan para sisya termasuk anggota keluarga dulu dominan menggunakan bahasa Bali halus (singgih), namun sekarang kebanyakan menggunakan bahasa Indonesia dan bahkan menggunakan hand phone. Masing-masing anggota Griya sibuk mengurus diri sendiri terkait dengan tugastugas mereka seperti sebagai PNS, kuliah, sekolah dan pekerjaan lainnya. Mereka nampak tidak terlalu terikat dengan aturan/dresta lama yang dulu mereka anut. Disini nampak nilai-nilai budi pekerti yang diwariskan sebagai dresta sudah mulai bergeser atau melemah (observasi di beberapa Griya di Kabupaten Buleleng,12 Juni 2013). Pendidikan budi pekerti merupakan suatu usaha atau yang mengantarkan anak menjadi dewasa, memiliki moralitas yang luhur atau akhlak yang mulia. Kitab suci veda adalah sumber ajaran agama Hindu yang 
sangat universal dan kompleks perlu dikaji secara detail tentang ajaran-ajaran budi pekerti yang terkandung di dalamnya.

Untuk mengkaji nilai-nilai budi pekerti dalam ajaran Weda dan implementasinya dalam masyarakat Geriya di Kabupaten Buleleng.Beberapa konsep penting yang terkait dengan gejala penelitian sebagai berikut. Prihal Griya; adalah tempat tinggal para brahmana/pendeta/sulinggih,merupakan tempat yang telah disucikan melalui prosesi upacara, mempunyai aturan atau tatakrama yang berlaku untuk siapaun yang masuk ke Griya, Soken Bandana (2012:44), Wiana (2006:70), Pemprov Bali (1985:66-67) disimpulkan bahwa, sulinggih, pedanda, bujangga, resi, bhagawan, empu adalah gelar kehormatan yang diberikan oleh seorang nabe melalui proses pendidikan yang disebut aguron-guron dan upacara dwijati selanjutnya diberikan tugas sebagai pemimpin upacara keagamaan. Pendidikan Budi Pekerti; Pendidikan budi pekerti yang dimaksudkan dalam penelitian ini adalah usaha sadar yang dilakukan dalam rangka menanamkan mengembangkan nilai, sikap dan perilaku siswa yang memancarkan akhlak mulia atau budi pekerti luhur dalam kehidupan sehari-hari, baik dalam berinteraksi dengan Tuhan, dengan sesama manusia maupun dengan alam atau lingkungan. Weda Sebagai Sumber Pendidikan Budi Pekerti; beberapa nilai budi pekerti yang ditanamkan kepada anak meliputi: (a) menanamkan Sraddha (Keimanan) dan Religiusitas, (b) berbhakti kepada orang tua, (c) mencintai dan menghormati guru, (d) mencintai dan menghormati saudara, kakak dan adik, (e) mencintai dan menghormati sahabat dan temanteman, (f) mencintai tanah air dan bangsa, (g) bersikap ramah dan berbicara manis, (h) mengembangkan kebajikan, (i) mengembangkan kesucian hati, (j) taat sembahyang dan rajin belajar, $(k)$ kebenaran dan pengorbanan serta kegiatan yang benar, (l) kedamaian dan kesabaran, $(m)$ kesetaraan gender, $(n)$ hak azasi manusia, (o) demokrasi dan musyawarah mufakat, (p) keadilan, (q) tanggungjawab, keuletan, dan kerjasama, $(r)$ penghargaan dan harmonis dengan lingkungan sosial dan alam. Dalam kaitannya dengan judul penelitian ini ada beberapa teori yang digunakan antara lain: teori perilaku, teori psikologi massa, teori simbolis, teori relegi, teori makna, teori persepsi, teori hegemoni.

\section{METODE}

Penelitian ini dirancang dengan penelitian emperik jenis deskriptif kualitatif merupakan penelitian yang konsen pada kontek yang bersifat naturalistik. Subyek penelitiannya adalah masyarakat atau semua warga yang ada dalam Geriya yaitu: sulinggih (lanang istri), keluarga inti (ayah, ibu dan anak), para pembantu rumah tangga serta para pengayah (sisya, tukang banten dan lain-lain yang memiliki ikatan emosional atau tunduk dalam tatakrama/adat-istiadat Geriya). Penelitian ini juga menggunakan beberapa pendekatan terhadap gejala yang diteliti yaitu: fenomenologis, interaksi simbolis, kebudayaan dan etnometodologi (Bogdan dan Biklen, 1982). Teknik Penentuan informan (Sampel) yang digunakan adalah purposive sampling dengan teknik snowball. Metode pengumpulan data yang digunakan dalam penelitian ini adalah wawancara, observasi dan dokumentasi/pencatatan dokumen. Sedangkan analisis data yang digunakan adalah: deskriptif kualitatif. 


\section{Hasil dan Pembahasan}

\section{Implementasi Ajaran Sradha dalam Kehidupan Sehari-hari}

Berdasarkan hasil observasi dan wawancara terhadap responden berkaitan dengan implementasi ajaran Sradha dalam kehidupan sehari-hari di lingkungan Griya diperoleh temuan bahwa, secara umum ajaran Sradha (keyakinan terhadap Tuhan Yang Mahakuasa) masih tetap ajeg dan bahkan semakin mantap dibandinkan dengan tahun-tahun sebelumnya. Sulinggih sebagai tokoh spiritual menerapkan ajaran sradha khususnya sembahyang dilakukan ratu sulinggih setiap hari $3 \times$ sehari sesuai dengan waktu yang telah ditentukan. Upacara nyurya sewana misalnya, sulinggih melakukannya pada setiap pagi menjelang matahari terbit.

Pemujaan Bhatara Siwa dalam manifesitasi Dewi Sawitri dengan Sawitri Mantram sepenuhnya ditujukan untuk menjaga kebenaran alam dan merawat kebaikan manusia. Beliau juga selalu menyarankan kepada seluruh anggota keluarga inti maupun para sisyanya agar selalu melaksanakan atau maturan setiap hari seperti ngaturang wedang di pelinggih panunggun karang, ngejot (ngaturang saiban atau nasi dan lauk seteleh selesai memasak) serta ngaturang canang sari setiap hari selalu dilakukan oleh keluarga inti di Geriya. Jika ada pujawali di merajan Geriya, para sisya sudah mulai aktif ngayah guna mempersiapkan sarana persembahyangan, sepereti banten, makanan dan semua perlengkapan upakara. Dalam interaksi mereka saat ngayah sudah mencerminkan bagaimana dari orang yang lebih tua agar selalu menjadi panutan baik dari cara bertutur kata, berpenampilan yang baik serta sopan santun dalam berkomunikasi baik dengan ratu peranda maupun dengan sesama pengayah atau sisia. Di sisi lain, ratu sulinggih sebagai orang yang disucikan secara tidak langsung ikut terlibat dalam hal pembinaan terhadap umat khususnya menanamkan budi pekerti. Upaya tersebut dilakukan kepada sisya yang tangkil yaitu dengan cara menjadi contoh yang baik khusunya dalam hal berpenampilan, bertutur kata yang sopan santun. Dharma tula juga sering dilaksanakan karena, menurut ratu sulinggi sangat efektif dalam hal pembinaan umat baik yang menyangkut ke hal-hal spiritual maupun hal-hal yang sifatnya moral. Selain kepada para sisyanya, sulinggih juga selalu menjadi panutan kepada tukang banten yaitu beliau yang memiliki kesiapan lahir dan bathin untuk menjadi pelayan dipura atau tempat-tempat suci. Para sarathi melayani semua tanpa kecuali. Para tukang banten ini, mereka harus melewati ritual penyucian "mawinten" sehingga peran tukang banten itu menjadi sangat komplit, yaitu tidak hanya pintar dalam hal membuat banten, namun juga harus selalu dilandasi dengan kesucian hati dan ketulusan jiwa, sebab banten yang mereka buat itu nantinya akan dipersembahkan kehadapan Ida Sang Hyang Widhi Wasa. Jadi sudah selayaknya juga tukang banten memperhatikan ratu sulinggih untuk menjadikannya panutan baik dalam berpikir, berbicara dan berbuat. Penerapan ajaran sradha juga nampak dari kesemarakan dalam berupacara baik dalam purnama-tilem maupun pujawali di merajan dan juga di luar Griya. Dari segi kesemarakan dapat dilihat dari peran/keterlibatan warga Griya dalam berupacara dan sarana prasarana atau alat-alat upacara yang digunakan.

Warga Griya nampak sangat antusias dalam mengikuti seluruh proses upacara. Semua warga Griya, anak-anak, orang dewasa termasuk para sisya dan pengayah/tukang banten ikut dalam proses upacara. Kesemarakan yang melibatkan jumlah warga, nampak juga dari pakaian yang digunakannya yaitu menggunakan pakaian adat lengkap. Berpakaian merupakan cetusan hati atau jiwa seseorang dalam berinteraksi dengan objek tertentu. Pakaian memberikan 
makna tertentu dalam suatu kehidupan sesuai kontek kegiatan seseorang. Seperti dijelaskan (Aditya, 2012, rahdeaditya@gmail.com) menjelaskan bahwa, simbol adalah formulasi yang paling baik dari sesuatu hal yang ada atau diharapkan ada. mengandung arti bagi kelompok manusia sebagai sesuatu yang mengandung milik bersama. Pakaian adat merupakan simbol identitas tradisi Bali bermakna hidmat mengikuti semua rangkaian upacara. Ekpresi ini menunjukkan bahwa keyakinan terhadap Tuham Yang Maha Esa cukup tinggi. Dalam keyakinan tersirat sifat-sifat ketekunan, keuletan, kesabaran, pengendalian diri, keiklasan dan tanggung jawab. Pola/model ini dari sudut kepemimpinan adalah: Ing arsa sungtulodo, Ing madya mangun karso dan Tutwuri Handayani (Kihadjar Dewantara, 1962). Sulinggih dan orang tua anak (walaka) di Griya telah menanamkan pola keteladanan, membangkitkan semangat bersama anak-anak serta para anggota termasuk sisya, dan juga memberiikan dorongan untuk beraktivitas secara mandiri. Donder (2007), kalau dilihat dari Teori Simbolis, ritual dalam bentuk persembahan sesaji yang dibuat dari berbagai sarana merupakan simbol ketulusan hati. Menurut Teori Simbolis, bahwa interaksi sesama manusia itu menggunakan simbol-simbol. Simbol digunakan untuk mewakili maksud seseorang. Teori Simbolis membenarkan penggunaan simbol-simbol untuk mewakili maksud yang hendak disampaikan. Jika seseorang lelaki mengirim surat kepada seorang kekasihnya, surat itu mewakili sang lelaki tersebut untuk menyampaikan perasaannya. Demikian pula upacara yang dilakukan oleh umat Hindu merupakan ungkapan hati yang hendak disampaikan kepada Tuhan. Teori di atas menguatkan bahwa aktivitas warga Griya memiliki simbol serta makna tertentu. Makakidungan atau pesantian dalam pelaksanaan upacara menunjukkan keihklasan, demikian juga "memejamkan mata" pada saat persembahyangan menunjukkan kesungguhan dan ke dalaman sradha dari yang berangkutan terhadap Tuhan Yang Maha Esa. Kesemarakan dilihat dari sarana atau alat-alat upakara yang digunakan nampak cukup meriah seperti: busana pelinggih, penjor upacara, umbul-umbul, banten dan suara gong dari kaset. Semua symbol tentang kesemarakan tersebut memiliki makna bahwa penerapan sradha di lingkungan Griya masih cukup baik dalam perkembangan di era globalisasi ini. Pengamalan srdha juga ditunjukkan dengan kemampuan oleh warga Griya dalam bertrisandhya dan kramaning sembah. Semua warga Griya dapat mengucapkan mantram Tri Sandhya termasuk anak-anak yang telah berusia 7 tahun ke atas (usia anak Sekolah Dasar ke atas). Disamping itu Griya adalah tempat pembinaan spiritual dimana bentuk kegiatannya sangat bervariasi antara lain: kegiatan aguron-guron (pendidikan dan pelatihan kepemangkuan/kesulinggihan), pesantian, pelatihan tukang banten dan lain-lain. Melalui proses inilah merupakan media untuk menanamkan nilai-nilai budi pekerti.

Dalam kegiatan ini sulinggih menyampaikan tuntunan etika, sikap dan sopan santun yang disebut sesana manut linggih (tata cara bersikap dan perilaku sesuai dengan kedudukan/tugas/fungsi). Dalam proses aguron-guron ini juga sering dihadirkan tokoh-tokoh lembaga umat Hindu seperti: ketua Mahagotra Pasek Sanak Sapta Rsi Kabupaten Buleleng, ketua Parisadha Hindu Dharma Indonesia Kabupaten Buleleng dan tokoh-tokoh lain. Beliau-beliau yang hadir juga memberikan dharma wacana. Pemedek atau umat memohon tuntunan pelaksanaan yadnya. Ratu Pranda/Sulinggih dalam setiap kesempatan memberiikan tatacara pelaksanaan yadnya. Tradisi ini secara langsung dan tidak langsung adalah proses menanamkan bhakti/sradha kepada generasi muda. Metode ini sangat efektif membentuk sikap dan perilaku berdasarkan nilai-nilai budi pekerti. Dari uraian di atas menunjukkan bahwa Griya adalah tempat atau 
proses transfer nilai-nilai Agama Hindu, budi pekerti kepada anak, agar sikap perilakunya dapat mencerminkan pengamalan ajaran agama serta mensyukuri penjelmaan sebagai manusia dengan tekad untuk memperbaiki karma menuju kebaikan.

\section{Implementasi ajaran bhakti terhadap orang tua, guru, saudara, sahabat, orang lain di lingkungan Griya}

Ajaran bhakti ditunjukkan dengan sikap dan perilaku normatif kepada orang tua, guru, saudara, sahabat, orang lain di lingkungan Griya. Sikap dapat tercermin dalam ekpresi berinteraksi dengan orang lain. Dalam masyarakat Griya interaksi dapat digolongkan sebagai berikut. Interaksi sulinggih dengan para walaka. Walaka dengan walaka usia sebaya, walaka dengan usia yang lebih muda. Impementasi ajaran bhakti khususnya rasa hormat kepada orang tua, ratu sulinggih memaparkan bahwa orang tua menanamkan nilai moral kehidupan masa depan baik dalam mengemban dharma agama dan dharma negara. Nasihat yang beliau terima dari orang tua juga selalu diteruskan kepada anak cucu dan umat melalui dharma thula sehingga semakin efektif dan mengena kepada para sisyanya.

Sebagai orang yang disucikan, tentu menjadi sebuah keharusan bagi seorang sulinggih untuk selalu berkata dengan bijak melalui bahasa yang halus, tidak kasar apalagi dengan nada yang keras atau intonasi yang menghardik. Sulinggih memberikan pelayanan yang sangat baik kepada semua pemedek yang tangkil ke Grya beliau menyapa dengan menggunakan bahasa bali halus. Terkait dengan penggunaan bahasa dari pengamatan peneliti ditemukan penggunaan kata "Ratu", "Pranda", Bapa" untuk sulinggih brahmana (Pranda). Contoh penggunaannya "Ratu lakar mapuja" (Saya akan melakukan pemujaan). Kata "Bapa", Empu", "Pandita" sebagai pengganti kata "Saya" digunakan oleh sulinggih dari warga Pasek. Contoh penggunaannya "Pandita / Empu lakar mapuja" (Saya akan melakukan pemujaan). Kata "bapa" sebagai pengganti kata "saya" jarang bahkan tidak digunakan lagi dalam percakapan sehari-hari di Griya oleh sulinggih. Dilihat dari tinggkatan bahasa yang digunakan dalam percakapan sehari-hari oleh subyek sulinggih kepada anggota walaka di lingkungan Griya kebanyakan menggunakan bahasa bali madia seperti, "Mai dini negak" (mari di sini duduk) kata ini digunakan oleh sulinggih kepada para sisya ataupun pengayah di Griya. Dalam percakapan berikutnya selain bahasa bali madia, sulingih juga menggunakan bahasa campuran antara bahasa bali madia dengan bahasa Indonesia. Dari walaka ke sulinggih menggunakan bahasa bali singgih/halus. Contoh "Ratu, titiang ngelungsur mapamit" (Ratu, saya mohon permisi). Sedangkan antar walaka menggunakan bahasa campuran yaitu bahasa bali madia dan bahasa Indonesia.

Namun lingkungan Griya warga brahmana komunikasi antar walaka menggunakan bahasa bali singgih/halus. Bahasa merupakan refleksi sikap atau budi pekerti seseorang. Penggunaan bahsa secara integral diikuti oleh ekspresi wajah atau pun bahasa tubuh lainnya. Seperti sikap hormat/bhakti nampak dalam cara atau gaya mereka (walaka) dalam berbicara. Dalam ajaran Weda dijelaskan "Hendaknya anak-anak patuh, berbhakti kepada kedua orang tua dan menyenangkan hati ibunya" (Atharvaveda, III.30.2). Sikap sopan santun sangat terasa dalam komunikasi antar warga di lingkungan Griya. Sulinggih berbaur dengan anak dan cucu beliau dengan sangat ramah menerima salam dan ciuman tangan dari anak cucu. Dalam kesibukan beliau sebagai tokoh spiritual beliau selalu meluangkan waktu untuk berkomunikasi dengan anak cucu dan 
para sisya lainnya. Sikap sopan santun ditunjukkan oleh anak (walaka) dengan senyum dan menundukkan kepala. Disamping bahasa tubuh, penggunaan bahasa lisan sebagai alat komunikasi juga dapat menunjukkan sikap dan perilaku. Makna yang terkandung di balik penggunaan bahasa seperti arus komunikasi dari walaka kepada sulinggih yaitu menggunakan bahasa bali halus/singgih. Makna bhakti atau hormat kepada sulinggih ditunjukkan dari bahasa yang digunakan seperti; "Ida anak lingsir" sampun ngrayunang" (Ida Sulinggih sudah makan)? "Ratu Pranda sampun ngrayunang"? (Ratu Pranda sudah makan)? Berdasarkan pengamatan peneliti semua walaka baik warga Griya, termasuk sisya, tukang banten termasuk tamu yang berkunjung ke Griya menggunakan bahasa bali halus/singgih jika berkomunikasi dengan sulinggih (Pranda atau Empu). Ini menunjukkan bahwa ajaran budi pekerti masih terimplementasi secara baik dalam kehidupan sehari-hari di Griya. Tidak saja digunakan kepada sulinggih namun bahasa halus juga sering digunakan dalam berkomunikasi antar walaka dalam lingkungan Griya. Hal ini sesuai dengan teori makna Menurut Sastra (2010) mengemukakan bahwa makna adalah hubungan antara makna dengan pengertian. Makna adalah pengertian atau konsep yang dimiliki atau terdapat pada suatu tanda linguistic.

Bahasa menunjukkan sikap dan perilaku para penuturnya. Bagaimana makna ini ditanamkan para responden menjelaskan bahwa bagi warga Griya adat/kebiasaan penggunaan bahasa bali halus adalah sesuatu yang biasa, bukan sesuatu yang baru. Walau pun dalam perkembangan jaman ini banyak bahasa Indonesia digunakan dalam komunikasi namun haya sebatas selingan disebabkan keterbatasan penguasaan bahasa bali halus/singgih oleh penuturnya.

Persoalan benar salahnya struktur kalimat yang digunakan dalam berkomunikasi tidak terlalu menjadi perhatian. Mereka lebih menekankan maksud dan makna yang dimaksud. Warga Griya dari Brahmana telah mewariskan penggunaan bahasa halus singgih dari nenek moyang mereka. Peran Sulinggih sangat berpengaruh dalam menumbuh-kembangkan dan melestarikan budaya ini. Sedangkan bagi warga Griya non-brahmana justru menjadi sesuatu yang baru. Mereka belum terbiasa menggunakan bahasa halus/singgih dalam berkomunikasi. Dalam hal ini nampak nama "Griya" khusus di Bali mempunyai pengaruh yang sangat tinggi untuk merubah sikap dan perilaku seseorang.

Disamping nama Griya pigur sulinggih juga berpengaruh besar. Nama Griya dan sulinggih menghegemoni masyarakat Bali untuk tunduk pada dresta yang berlaku di Griya. Gramsci (dalam http://synaps,wordpress,com) hegemoni didefinisikan sebagai dominasi oleh satu kelompok terhadap kelompok yang lain, dengan atau tanpa ancaman kekerasan, sehingga ide-ide yang didiktekan oleh kelompok dominasi terhadap kelompok yang didominasi/dikuasai diterima sebagai sesuatu yang wajar dan tidak mengekang pikiran. Mendengar kata "Griya" masyarakat hindu sudah terbentuk persepsi bahwa siapapun yang masuk ke Griya harus tuntuk dengan dresta (adat istiadat di Griya terebut). Kata "harus" di sini mengandung makna otoriter/memaksa, namun bagi masyarakat termasuk para sisya dan tukang banten tidak merasa tepaksa (terhegemoni). Bentuk bhakti umat kepada sulinggih dinyatakan dalam yadnya (berkorban secara tulus inklas tanpa pamrih).

Yadnya yang dipersembahkan sebagai rasa bhakti kepada sulinggih seperti: ngaturang ayahan/karma punia (membantu secara tulus inklas berupa pekerjaan pisik), arta punia (membantu secara tulus inklas berupa arta benda), dana punia (membantu secara tulus ihklas berupa uang), dan yang lainnya. 
Ketika di Griya ada ajatan upacara, banyak para sisya dan pemedek lainnya datang maturan ayahan dan barang-barang berupa: buah-buahan, alat/sarana banten (kelapa, bungkak, busung, dan lain-lain). Menurut responden mereka (para sisya, pengayah, tukang banten dan warga lain) maturan atas dasar kemauan sendiri tanpa dikondisikan. Konsep bhakti antar anggota keluarga inti di Griya, ditemukan ada perbedaan antara Griya dari Brahmana dengan nonbrahmana. Pada Griya Brahmana hubungan tata krama yang menyatakan etika/sopan santun lebih alami. Hal ini ditunjukkan dalam penggunaan bahasa beserta ekspresi dan bahasa tubuh (body language). Bahasa bali halus hanya nampak dalam percakapan ida anak linggir (sulinggih lanang dengan istri) dan walaka dengan sulinggih. Sedangkan walaka dengan walaka menggunakan bahasa bali kepara (bahasa bali dalam pergaulan) hanya saja istilah "tiang, nike, sampun, durung" selalu digunakan. Sikap bhakti dapat pula terekspresi dari pakaian yang digunakan oleh warga Griya. Di Griya orang-orang sudah terbiasa menggunakan pakaian adat madya untuk kegiatan sehari-hari. Hampir setiap hari tempat madya mandala tidak pernah sepi dari kegiatan. Sisya, tukang banten maupun pengayah berjam-jam bahkan berhari-hari menghabiskan waktunya tanpa mengenal lelah di tempat ini. Motivasi mereka adalah adalah "ngayah" kata "ngayah" mengandung makna "yadnya" yaitu korban suci secara tulus inklas tanpa pamrih kehadapan Tuhan Yang Maha Esa dan juga kepada ida Sulingih. Konsep hukum karma phala menjadi motivasi instrinksik untuk bersikap dan berperilaku. Keyakinan mereka adalah "berbuat baik atau beryadnya sebanyakbanyaknya niscaya akan mendapat phala atau hasil yag baik pula asal dilaksanakan dengan tulus inklas tanpa pamrih. Dibalik yadnya atau keihklasan berkorban menunjukkan dalam tidaknya rasa bhakti seseorang.

\section{3) Mencintai Tanah Air, Bangsa dan Negara}

Keluarga sebagai tempat pendidkan yang pertama dan utama mempunyai peran yang sangat penting dalam pembentukan karakter/moral anak. Orang tua sebagai pendidik telah menanamkan proses pendidikan karakter dari sejak anak dalam kandungan (pendidikan prenatal) melalui pembiasaan, bersikap/berperilaku yang baik selama ibu mengandung. Konsep ajaran Tri Kaya Parisudha dan hukum karma phala merupakan konsep yang cukup efektif untuk dijadikan dasar/pedoman dalam menuntun sikap dan perilaku agar terhindar dari hal-hal yang tidak diinginkan. Berpikir, berkata dan berbuat yang benar menurut aturan/norma yang berlaku diyakini memperoleh phala yang baik pula. Demikian sebaliknya berpikir, berkata dan berbuat yang tidak baik diyakini dapat mengakibatkan kesengsaraan.

Dalam masyarakat Griya nampaknya konsep ajaran ini telah terimplikasi secara baik dan bahkan dilengkapi dengan upacara sesuai dengan tahapan/usia kehamilan ibu. Dengan demikian anak yang lahir diharapkan memiliki sikap/kepribadian yang baik seperti diharapkan. Penanaman dasar kepribadian sangat tepat dalam usia dini karena jiwa anak masih bersih. Dalam kondisi yang "bersih" belum terkontaminasi dari berbagai pengalaman lain sangat tepat untuk mentransformasi nilai-nilai cinta Tanah Air, Bangsa dan Negara.

Model penerapan pendidikan ini mengikuti teori John Locke (1693) dalam teori tabula rasa adalah bahwa pikiran (manusia) ketika lahir berupa "kertas kosong" tanpa aturan untuk memroses data, dan data yang ditambahkan serta aturan untuk memrosesnya dibentuk hanya oleh pengalaman alat inderanya. Seperti dijelaskan oleh responden bahwa, mendidik anak agar yang bersangkutan memiliki kepribadian cinta Tanah Air dan Bangsa yaitu pada saat anak masih kecil dan bahkan dari sejak ibu mengandung. Namun dalam proses 
perkembangan anak selalu tumbuh dan berkembang sesuai dengan lingkungannya.

Dengan demikian teori tabularasa sudah mulai dikombinasikan dengan teori lingkungan. Sikap dan perilaku cinta Tanah Air, Bangsa dan Negara mengandung unsur kasih dan sayang terhadap sesuatu (tanah air, bangsa dan negara). Kemudian, dalam diri akan tumbuh suatu kemauan untuk merawat, memlihara dan melindunginya dari segala bahaya yang mengancam. Cinta tanah air berarti rela berkorban untuk tanah air dan membela dari segala macam ancaman dan gangguan yang datang dari bangsa manapun. Para pahlawan telah membuktikan cintanya kepada tanah airnya yaitu tanah air Indonesia. Mereka tidak rela Indonesia diinjak-injak oleh kaum penjajah. Mereka tidak ingin negerinya dijajah, dirampas atau diperas oleh bangsa penjajah. Mereka berani mengorbangkan nyawanya demi membela tanah air Indonesia. Dalam kaitannya sikap cinta tanah air dalam kehidupan sehari-hari, berdasarkan hasil pengamatan peneliti ditemukan bahwa: belajar dengan tekun (bagi anak-anak sekolah), menjaga kelestarian lingkungan, tidak memilih-milih teman, berbhakti pada nusa dan bangsa, berbhakti pada orang tua.

Dalam tatakrama pergaulan atau komunikasi antar personal di Griya ditemukan bahwa, semua hal di atas telah terimplementasi dalam kehidupan sehari-hari. Seperti kegiatan "belajar dengan tekun" khusus bagi anak-anak. Di tempat penelitian tidak ada anak yang putus sekolah. Sebagian besar anak-anak di Griya sukses dalam pendidikan. Sulinggih dan juga orang tua (walaka) sangat memperhatikan pendidikan anak-anak mereka. Orang tua selalu menanyakan apa ada "PR" atau tidak kepada anak-anaknya. Bertanya prihal pendidikan anak mempunyai makna bahwa orang tua sangat perhatian tentang pendidikan anaknya disamping itu juga mengandung makna "tanggungjawab" bahwa keberhasilan pendidikan anak adalah keberhasilan orang tua. "Menjaga kelestarian lingkungan" dalam maasyarakat Griya diimplementasikan dengan cara: menjaga kebersihan lingkungan, menjaga alat-alat, barang milik sendiri ataupun milik bersama, tidak membuang sampah sembarangan. Berdana punia untuk membangun tempat-tempat umum adalah juga pengamalan bakti kepada bangsa, hal ini juga dilakukan oleh warga Griya dimana sulinggih menekankan perbuatan yadnya/ berdana punia adalah perbuatan yang mulia.

Ajakan ini sering disampaikan oleh sulinggih kepada para sisya dan anggota Griya yang lainnya dalam setiap kesempatan di Griya. Konsep berdana punia ini dipahami dan dilaksanakan oleh warga Griya seperti memberiikan sumbangan kepada panti asuhan, pembangunan pura dan pasraman. Sisya yang sedang maguron-guron juga memberiikan punia dan diserahkan oleh perwakilan sisya kepada ketua Mahagotro Pasek Sanak Sapta Rsi kabupaten Buleleng pada saat pawintenan, disaksikan oleh Ida Sulinggih. Dana punia secara tulus ihklas dikumpulkan oleh para sisya tanpa ada paksaan. Menurut para sisya berdana punia secara tulus inklas adalah perintah Tuhan/lda Hyang Widhi Wasa yang tertulis dalam kitab Weda. Contoh mapunia (pemberian sedekah) ini menjadi panutan bagi seluruh warga Griya.

Aplikasi ajaran bakti terhadap negara dilaksanakan dengan menjaga kebersihan lingkungan. Griya adalah tempat spiritual dimana banyak orang-orang yang bekerja membuat banten sehingga dapat dipastikan produksi sampah sangat banyak. Namun manajemen kebersihan di Griya sudah tertata dengan baik. Dibeberapa sudut ditaruh bak sampah dan bak sampah berfungsi dengan baik. Disamping itu sebelum menghakhiri pekerjaan diadakan kebersihan bersama oleh para pengayah. Bilamana pekerjaan pada hari tersebut belum tuntas, maka dilanjutkan oleh keluarga inti. Menjaga kebersihan linkungan 
merupakan pengamalan dharma negara. Membiasakan bersih lingkungan keluarga merupakan kewajiban dari setiap anggota Griya. Disamping kebersihan, penataan halaman juga merupakan bagian dari cinta tanah air. Dari hasil observasi khususnya di Griya tempat penelitian menunjukkan bahwa areal Griya cukup asri. Banyak tumbuh-tumbuhan ditanam yang tertata secara rapi dari nista mandala, madya sampai pada utama mandala. Jenis tanaman bervariasi dari berbagai bunga yang bermanfaat untuk keperluan upacara, dan tanaman lain yang diperlukan untuk upacara sampai pada jenis tanaman hias. Dalam konsep ajaran agama Hindu di Griya pengamalan konsep Tri Hita Karana cukup baik. Pengamalan tentang "tidak memilih-milih teman" dapat dibuktikan dari proses komunikasi dan pergaulan di Griya cukup padat hampir setiap hari di Griya terdapat kegiatan yang melibatkan banyak orang di luar keluarga inti. Mereka bekerja, bergaul, berkomunikasi dengan penuh persaudaraan. Mereka tidak pernah memilih dan memilah orang sebagai fatner kerja.

\section{4) Implementasi Ajaran Sopan-santun}

Griya sebagai tempat pendidikan yang pertama dan utama tentu memegang peran penting dalam pembentukan kepribadian anak. Kepribadian seseorang terekspresi dalam sikap dan perilakunya sehari-hari. Dari hasil penelitian dapat dijelaskan, implementasi sopan santun dalam kehidupan masyarakat di Griya sangat baik hal ini dilihat dari tata cara berpakaian. Masyarakat/warga Griya sudah terbiasa menggunakan pakaian adat madia dalam kehidupan sehari-hari. Bagi warga Griya inti (orang tua dan anak-anaknya) memang nampak tidak sepenuh waktu dalam sehari menggunakan pakaian adat. Ada waktu-waktu tertentu mereka menggunakan pakaian yang bukan pakaian adat. Pakain ini digunakan sesuai dengan jenis kegitan yang dilakukannya. Seperti kegiatan berkebun, memberiisihkan motor/mobil, istirahat/releks dan akan berangkat kerja. Khusus anak-anak yang masih sekolah mereka menggunakan pakaian adat pada saat kegiatan keagamaan selebihnya mereka berpakaian biasa (bukan adat). Kegiatan di Griya bisa dikatakan tidak pernah sepi dari kegiatan keagamaan. Kegiatan keagamaan ini merupakan media yang sangat tepat dan berkontribusi signifikan dalam membina sikap sopan-santun di Griya.

Berpakaian adalah bagian dari penampilan seseorang yang berpengaruh terhadap tutur kata dan perilaku seseorang. Sebagian besar warga Griya menggunakan bahasa bali madia dalam berkomunikasi kecuali dengan Ida Sulinggih. Penggunaan bahasa bali madia oleh warga Griya adalah cerminan sikap sopan santun. Berdasarkan hasil pengamatan selama berada di Geriya Tohpati, bahasa yang digunakan oleh penutur dengan lawan bicaranya yaitu sangat baik. Hal itu terlihat dari bahasa bali halus yang selalu digunakan oleh walaka untuk berkomunikasi dengan ratu sulinggih. Akan tetapi jika ada bahasa yang mungkin agak susuah dipahami ratu peranda menjelaskan dengan menggunakan bahasa Indonesia. Ini berarti pola komunikasi yang diterapkan ratu sulinggih sangatlah fleksibel dan memamami kondisi yang ada. Tidak hanya berbicara saja yang baik dituntut dalam berinteraksi dengan ratu sulinggih. Perilaku yang muncul dalam percakapan yaitu dari sikap duduk sampai sikap tangan juga menunjukkan rasa hormat para sisya, para pemedek yang tangkil ke Griya. Seperti duduk bersila dengan tangan selalu dicakupkan di ulu hati (posisi mudra), sehingga sudah cukup menggambarkan bahwa para pemedek yang tangkil sudah paham betul bagaimana cara menunjukkan rasa bakti dan hormatnya kepada sulinggih tersebut. Pakaian yang sering dipergunakan oleh para pemedek yang tangkil yaitu menggunakan pakaian adat madya yaitu 
dengan menggunakan kamben dan baju kebaya lengkap dengan kain selendang bagi para wanita, sedangkan bagi yang pria menggunakan kamben, selendang serta menggunakan udeng atau destar. Nampak sedikit ada perbedaan antara warga Griya Brahmana dengan Griya bukan Brahmana dari segi penggunaan bahasa komunikasi.

Pada Griya Brahmana, penggunaan bahasa bali halus/singih lebih banyak. Ditemukan bahwa, semua sisya, tukang banten dan warga Griya lainnya termasuk masyarakat yang tangkil (masuk) ke Griya menggunakan bahasa bali halus/singgih tidak hanya kepada sulinggih tetapi juga kepada anggota keluarga inti. Dalam hal ini status Griya dari "Brahmana" juga berkontribusi cukup signifikan terhadap sikap sopan-santun. Dalam berinteraksi semua warga Griya melakukan aktivitas sesuai dengan tugas masing-masin dengan ramah, murah senyum, saling menyapa, manis tutur katanya, tidak mudah tersinggung. Perilaku ini adalah cerminan sikap sopan-santun. Bidang kegiatan yaitu spiritual nampak sebagai media atau alat yang efektif untuk meningkatkan sopan-santun.

Peran sulingih juga memegang peran penting dalam menanamkan nilainilai sopan-santun. Ida Sulinggih memberiikan tuntunan makna dan etika upacara kepada masyarakat Griya dalam setiap kegiatan upacara tertentu. Seperti foto di bawah ini sulingih berbaur dengan anggota keluarga lainnya saling memberii salam dengan sikap ramah. Hubungan yang akrab dan hangat memberii peluang pertumbuhan kepribadian yang baik pula sesuai dengan norma agama. Seperti foto di bawah ini hubungan sulinggih dengan para anggota keluarga dan masyarakat lain di Griya penuh dengan kehangatan. Kehangatan hubungan merupakan teknik pewarisan nilai-nilai budi pekerti termasuk nilai sopan santun. Memberi salam dengan menciptakan kehangatan hubungan antara sulinggih dengan sisya dan anggota Griya yang lainnya memberii kesan dan pengaruh yang baik secara psikologis bagi individu yang menerima atau diberi salam. Teknik ini merupakan tradisi yang biasa dilakukan oleh sulinggih setiap selesai melakukan kegiatan seperti kegiatan upacara. Hubungan orang tua dan anak yang positif adalah dasar untuk meningkatkan agar anak menjadi baik. Hal ini sesuai pendapat Titib (2006:127) dinyatakan bahwa, hal yang sangat penting mendapat perhatian adalah keteladanan atau suritauladan, contoh yang baik dari orang tua, dan siapa saja yang lebih tua. Sopan santun juga dapat dilihat dari cara duduk yang dilakukan oleh warga di Griya. Posisi kaki duduk seperti foto di bawah, tangan di depan dan pandangan atau perhatian yang serius tertuju kepada pembicara menunjukkan sikap sopansantun. Mereka tidak berbicara dengan orang lain ketika sulinggih sedang berbicara juga menunjukkan sikap sopan-santun.

Dengan menunjukan sikap yang memperhatikan, mendengarkan dengan baik, dan bila bertanya pun mereka menggunakan bahasa dengan dengan intonasi yang ramah dan menarik, menyenangkan orang yang mendengarkan. Dibalik keinginan mereka membantu ada motivasi yang terselubung yaitu mereka ingin belajar membuat banten/upakara serta bagaimana tatanan pelaksanaan upacara tersebut. Sebagian besar para pengayah memberiikan respon bahwa adanya kepercayaan atau keyakinan setiap orang yang mendorongnya untuk melakukan tindakan tersebut.

\section{5) Implementasi Ajaran Persamaan atau Kesetaraan Gender}

Dari beberapa sumber sastra ditemukan bahwa laki dan perempuan adalah sama dilihat dari penciptanya. Perbedaan yang terjadi adalah dalam hal peran atau kerjanya. Hal ini dipertegas oleh Triguna, dkk.,(2009) menjelaskan bahwa, laki-laki dan perempuan bersumber dari satu sumber yaitu Tuhan Yang Maha 
Esa. Satu berperan sebagai Jiwa Semesta dan satunya lagi sebagai Badan Semesta (purusa dan prakrti azas roh dan materi). Personifikasi dari dua aspek Tuhan tersebut disimbolkan sebagai Dewa dan Dewi, Raja dan Ratu.

Dalam era global ini kesetaraan gender dilihat dari tugas, hak, kewajiban dan peran dalam mengisi pembangunan. Laki-laki dan wanita mempunyai hak untuk dihargai dan menghargai, mempunyai peran dan kwajiban yang sama dalam mengisi pembangunan sesuai dengan potensi/kemampuan masing-masing. Dalam kehidupan masyarakat Griya dari hasil observasi dan wawancara dapat dijelaskan pelaksanaan kesetaraan gender adalah sebagai berikut. Wanita dan laki-laki mempunyai peran dan tugas yang jelas dalam setiap kegiatan. Sulinggih lanang-istri mempunyai tugas terkait dengan "ngelokopalasraya". Tugas sulinggih lanang: pemuput karya, memberii pelayanan tentang pedewasaan, memberii dharmawacana tentang tattwa, susila atau etika dan makna upacara. Sulingih istri bertugas sebagai "pengerajeg karya", meminpin sarathi/tukang banten dalam pembuatan upacara. Anara sulinggih lanang dan istri terdapat hak dan tugas yang sama sesuai dengan potensi dan porsi masing-masing. Tugas muput atau manggala upacara bagi sulinggih lanang adalah hak dan tugas utama. Beliau didiksha memang untuk menjadi manggala upacara. Demikian juga sulinggih istri hak dan tugas utama beliau adalah membantu sulinggih lanang dalam mempersiapkan pelaksanaan upacara termasuk memimpin pembuatan atau nyoroh banten.

Pengayah pengiring hak, tugas, kewajiban dan tanggung jawabnya adalah mendampingi sulinggih ketika beliau muput upacara. Tukang banten mempunyai hak, tugas, dan kwajibannya adalah membuat atau menyiapkan sarana banten/upakara. Sedangkan pengayah laki-laki tugasnya adalah membantu atau menyiapkan sarana upakara seperti: membuat kelatkat, sanggah cerukcuk, penjor dan lain-lain. Demikian juga para sisya yang lainnya sudah punya tugas masing-masing termasuk kegiata aguron-guron. Anggota keluarga inti masingmasing juga diberi peran yang berbeda-beda. Ada yang bertugas memasak, sembahyang (maturan canang sari) setiap hari, ada yang bertugas "ngejof", menyapu dan lain-lainnya. Pembagian tugas atau peran merupakan kewajiban yang harus dipertanggung-jawabkan oleh masing-masing individu. Hal ini menunjukkan adanya suatu proses pembiasaan/pendidikan tentang persamaan gender.

\section{SIMPULAN DAN SARAN}

Berdasarkan analisis di atas disimpulkan bahwa nilai-nilai budi pekerti yang terdapat dalam ajaran Weda ternyata dimplementasikan dengan baik oleg masyarakat Geriya di Kabupaten Buleleng. Dengan keterbatasan yang ada pada peneliti disarankan peneliti lain yang berminat untuk dapat mengembangkan aspek-aspek lain yang belum terjangkau agar hasil penelitian lebih sempurna.

\section{DAFTAR PUSTAKA}

Sudharta, Rai,Tjok. 2004. Slokantara, Untaian Ajaran Etika Teks, Terjemahan dan Ulasan. Surabaya: Paramita. 2009. Sarasamuccaya Smerti Nusantara. Surabaya: Paramita -,2010. Kumpulan Sloka Weda Suci. Himne Ilmu-ilmu Pengetahuan Eksata. Denpasar: Widya Dharma. 
Srimad Vyasaneyi Madyandina. 2005. Atharvaveda Samhita I. Surabaya: Paramita.

Sura I Gede. 2010.Pengendalian Diri dan Etika dalam Ajaran Hindu.(Serial Online), April. http://beguling.wordpress.com/

Titib I Made. 2006. Menumbuhkembangkan Pendidikan Budhi Pekerti Pada Anak. Perspektif Agama Hindu. Denpasar: Bali Post. 1996. Bhagavadvedah Sang Hyang Weda. Surabaya: Paramita.

Zubaedah Enik. 2009. Pola Pembinaan Budi Pekerti Anak di Panti Asuhan Darul Hadlonah Kucen Ungaran Semarang. Thesis. Tidak Diterbitkan. Semarang: Universitas Negeri. 